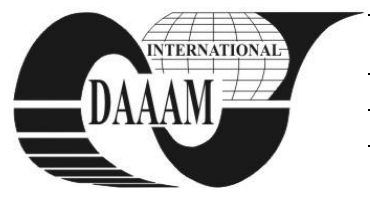

Annals of DAAAM for 2011 \& Proceedings of the 22nd International DAAAM Symposium, Volume 22, No. 1, ISSN 1726-9679 ISBN 978-3-901509-83-4, Editor B. Katalinic, Published by DAAAM International, Vienna, Austria, EU, 2011 Make Harmony between Technology and Nature, and Your Mind will Fly Free as a Bird Annals \& Proceedings of DAAAM International 2011

\title{
PERFORMANCE MANAGEMENT IN THE SPHERE OF PUBLIC ADMINISTRATION
}

\author{
PASTUSZKOVA, E[liska] \& PALKA, P[remysl]
}

\begin{abstract}
Performance evaluation of private sector institutions is usually based on profit as one of the main indicator and source of relevant information. However, the importance to monitor and manage performance at government institutions and institutions of public sector increases currently. This paper is focused on the issue of performance management at the level of public administration. The aim of this paper is to define a model based on the use of the main financial relationship among public administration and other economic subjects in case of the Czech Republic. This will be done using the " $3 E$ " principles (Economy, Effectivenes, Efficiency), which define the organizational performance on a global way.
\end{abstract}

Key words: performance, management, public administration, 3 E principles, financial relationships

\section{INTRODUCTION}

In the private sector, the measurement, monitoring and performance management is a common phenomenom. There are proven ways, methodologies and procedures, how to monitor the performance of businesses, including the usage of advanced technologies. In the public sector, however, there are still problems with using practical experience in the sphere of performance management. Although there is a growing tendency to monitor and improve financial performance, the public sector does not have as much variety of evaluation tools as the private sector. The main reason is that the public sector can not use methods based on the criterion of profit. Therefore, the practical problem remains in public sector how to set an optimal scale for measuring effectiveness without using the profit criterion.

This contribution presents views on the issue of performance management at the institutional level of public administration using the " $3 \mathrm{E}$ " principles, while seeking synergy effects of particular principles. In this way, the ongoing fundamental financial relationships among public administration of the Czech Republic on the one hand and other subjects of economy that are affected by these financial relationships on the other hand are analyzed. Financial relations in the form of taxes, subsidies and debt instruments have been selected as a test case.

\section{THEORETICAL BACKGROUND}

Although there is a general agreement about necessity of performance management implementation to the public sector, opinions of various authors differ and commonly accepted approach has not been delivered yet.

Public managers have no doubt about possibility of using of performance measurement for evaluation, controlling, budgeting, promoting and improving (Behn, 2003). Public authorities should also respond to "citizen demands for evidence of program effectiveness" (Wholey \& Newcomer,
1997). Performance measurement is in government attention especially since the time of New Public Management reforms (Hood, 1995, Lapsley, 2008, Arnaboldi, 2010). Although theoretically the issue of implementation of standards and performance management in organizations of public sector is well described, there is still a need for practical tools for their implementation (Modell, 2009). According to Jarrar \& Schiuma (2007), some doubts about "the practicality and feasibility of implementation on a large scale in public administration" raises.

Using of "3E" principles in performance management is no major innovation. Already Chambers \& Rand (1999) suggested that these principles can be successfully used in assessing the effectiveness of fiscal relations within the public sector. "3E" principles include primarily requirements for compliance of Economy, Effectiveness and Efficiency. Economy requires the lowest possible expenditure of funds within the appropriate quality. It is the evaluation criterion for input based on the principle of doing things inexpensively. Efficiency means achieving the necessary outputs with minimal financial sources, the relationship between inputs and outputs based on the principle of doing things the most suitable way. Effectiveness expresses the degree of progress towards the set objectives; it is the evaluation criterion for output based on the principle of doing only those things that really should be done.

\section{METHODOLOGY}

The basic financial relations of Czech public budgets taxes, subsidies and debt instruments are analyzed by authors' research team. These financial relationships are significantly influenced by preferences and expectations of the receivers on the one hand and providers of the fund on the other hand. Both sides, receivers of funds and providers, have different interests in upholding the " $3 \mathrm{E}$ " principles and another point of view on public administration performance. Institutions of public administration represent receivers in the case of taxes and debt instruments and in the case of subsidies; institutions are on the side of the payers. In the frame of the research, authors want to use " $3 E$ " principles for definition and evaluation of roles and preferences of public administrative institutions and other subjects involved into basic financial relations of public budgets. The authors set a model of relationships between payers and receivers of funds based on the " $3 \mathrm{E}$ " principles and specified synergy effects which can be used in performance management. This model will be verified in practice in the frame of further research work.

\section{RESULTS - USING OF "3E" PRINCIPLES IN PUBLIC MANAGEMENT}

Usage of "3E" principles in performance management of public administration shows following figure (Fig. 1). 


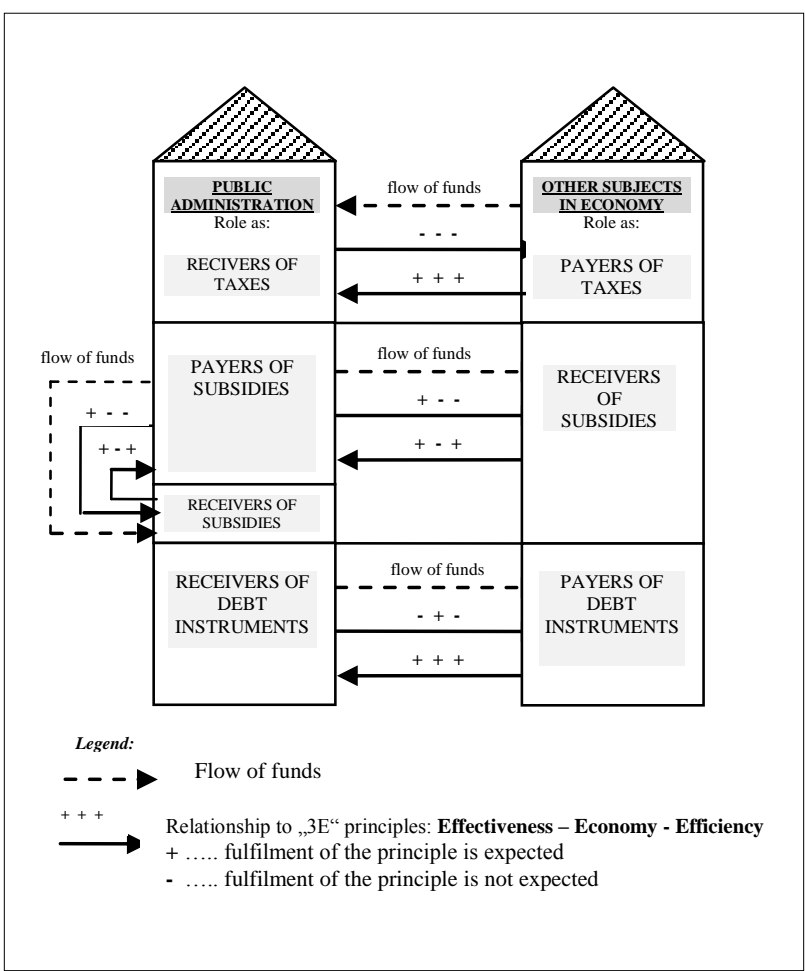

Fig. 1. Using of "3E" principles in financial relationships among public administration and other subjects in economy

In case of taxes, a positive relationship only in the direction from taxpayers to receivers is shown. Of course, taxpayers are interested in the question what happens with their money. On the other hand, in case of public administration and its budgets, we cannot find any relationship to one of these three principles. The aim of public institutions is to have sufficient amount of funds for financing all activities but linking to any input and output criterions is missing. As we can expect, synergy effect that would represent a tendency for using one of the "3E" principles on both sides is completely missing.

In the case of subsidies, public administration acts in a dual position. It can indeed be both a receiver and payer of funds. It represents receivers in that case if the funds are redistributed from one level of government to another. Here we can expect an emphasis on keeping of effectiveness principle from the providers' side (public administration) because providers usually bind subsidies with planned use. On the other hand providers usually do not expect usage of fewer amounts than is allocated to receivers. That is the reason why the economy and efficiency principles can be missing. In case of receivers of subsidies, which may be other economic subjects (natural persons, legal entities), but also public budgets on other governmental levels, focus on the efficiency and effectiveness principles which require the fulfillment of the objectives is expected. Alongside, receivers of subsidies are not motivated to manage these funds in accordance with the economy principle, because it is expected that they will try to exhaust whole granted amount and avoid a necessity to return the saved money back into public budgets. Then, synergy effect of subsidies is found in the focus on effectiveness.

In case of debt instruments, public authorities usually act as receivers and banks play the role of providers. Banks are aimed at fulfilling all three principles because institutions of private sector approach to performance management in a different way and above all they can use the criterion of profit as the basic category used in performance assessing. On the other hand, institutions of public administration are receivers which generally seek only for source of extra funds and they do not usually allocate them to specific spending programs. It can be assumed that the institution of public administration will seek to comply only with the economy principle. Other principles are tied to a way of their use and that is not always guaranteed in the case of provided funds.

\section{CONCLUSION - POSSIBILITIES FOR USING OF "3E" PRINCIPLES AND SYNERGY EFFECTS IN PUBLIC MANAGEMENT}

As noted, there is not a prerequisite for the existence of a common method for using "3E" principles to performance management in the sphere of basic financial relations among public authorities and other entities in case of Czech Republic. Arguably, a definition of general pattern of performance management for public authorities is currently impossible, because each sphere of administration has different requirements and different preferences. We can thus expand the Modell's (2009) idea that there is a gap between theory and practice of performance management in the public sector, because it is difficult to find common interests of subjects on both sides of financial relations.

Unlike the private sector, in case of public administration it is necessary to set criterions for performance monitoring different for each institution. Of course, this makes selfassessment and especially the comparison among public administration institutions very difficult. With using of " $3 \mathrm{E}$ " principles in performance management, managers of public administration can focus on those principles where, on one hand, a presumption of not sufficient use and respect is expected and, on the other hand, managers can encourage and support the positive synergy effects that can lead to performance increase because of their actions towards achieving efficiency, economy and effectiveness. In further research, the model will be verified in practice.

\section{ACKNOWLEDGEMENTS}

This paper was carried out with the financial support from IGA TBU No. IGA/70/FaME/10/A.

\section{REFERENCES}

Arnaboldi, M. (2010). Constructing performance measurement in the public sector. Critical Perspectives on Accounting, pp. 266-282, ISSN: 1045-2354, Vol. 21 , No. 4

Behn, R. D. (2003). Why Measure Performance? Different Purposes Require Different Measures. Public Administration Review, pg. 586, ISSN:1540-6210, Vol. 63

Hood, C. (1995). The New Public Management in the 1980s: variations on a theme. Accounting, Organizations and Society, pp. 93-109, ISSN: 0361-3682, Vol. 20

Chambers, A.D.; Rand, G. (1999). The Operational Auditing Handbook, Auditing Business Processes. John Wiley\&Sons, Chichester

Jarrar, Y.; Schiuma, G. (2007). Measuring performance in the public sector: challenges and trends. Measuring Business Excellence, pp. 4-8, ISSN: 1368-3047, Vol. 11, No. 4.

Lapsley, I. (2008). The NPM agenda: back to the future. Financial Accountability \& Management, pp. 77-96, ISSN: 1468-0408, Vol. 24, No. 1

Modell, S. (2009). Institutional research on performance measurement and management in the public sector accounting literature: a review and assessment. Financial Accountability and Management, pp. 277-366, ISSN: 14680408, Vol. 25, No. 3

Wholey, J.S.; Newcomer, K.E. (1997). Claryfiing Goals, Reporting Results. Using Performance Measurement to Improve Public and Nonprofit Programs, New Directions for Evaluation 75, Newcomer, K.E. (Ed.), pp. 91-98. CA: Jossey-Bass, SanFrancisco 